\title{
Effectiveness of Health Education Using Audio-Visual Media on Changes in Adolescent Knowledge and Attitudes About Obesity in SMPN 1 Pekanbaru
}

\author{
Rahmi Pramulia Fitri $\mathrm{S}^{1}$, Iyang Maisi Fitriani ${ }^{1}$ \\ \{rahmipramulia86@gmail.com ${ }^{1}$ \} \\ STIKes Payung Negeri, Pekanbaru, Riau ${ }^{1}$
}

\begin{abstract}
The message delivered can be fact, fictive, informative, educative, or instructional. The presence and development of this Audio Visual Aid (AVA) is inevitable, considering the strengths can give more real descriptions and improve memory retention because it is more interesting and easy to remember. The type of this research was quasi-experimental research. This research aimed to figure out the effectiveness of health education by using AVA towards the change of Teenagers' Knowledge of Obesity. This research was conducted at State Junior High School 1 Pekanbaru. The population total number of 435 students to be the samples. The technique of taking the sample was by using Random Probability Sampling. Data-dependent T statistic test analysis with the degree of reliability $95 \% \mathrm{p}=0,05$. The research results show that before and after conducting health education at State Junior High School 1 Pekanbaru by using AVA media is proven more effective.
\end{abstract}

Keywords: Obesity, Video, Audio Visual, Knowledge

\section{Introduction}

Obesity or overweight is a condition that occurs when the quantity of body fat tissue fraction compared to total body weight is greater than normal [1]. The tendency of obesity in adolescents is increasing rapidly throughout the world, both in developed countries and developing countries, including in Indonesia. Based on the results of research conducted in 14 major cities in Indonesia, the incidence of obesity in adolescents is relatively high, which is between $10-20 \%$ and is expected to continue to increase [1].

The presence and development of this Audio Visual Aid (AVA) media cannot be avoided considering the excess bias provides a more realistic picture and increases memory retention because it is more interesting and easy to remember. The advantages of Audio-Visual Aids (AVA) media can improve the interest in counseling and can help to achieve the goals of the counseling [2].

Nutrition problems in Indonesia have led to complex problems. The problem of undernutrition is still not completely resolved, while the problem of over-nutrition has emerged. The over nutrition that causes obesity can occur both in children to adulthood. Obesity is caused by an imbalance amount of energy with the needs of the body for biological functions such as physical growth, development, activity, and health maintenance.

World Health Organization (WHO) states there will be one billion people in the world, especially in urban areas, who have obesity or overweight. This number is to continue to 
increase in 2015 with the number of obese as 1.5 billion people. It is considered normal, as urban people living under economic demands and forget the healthy lifestyle. The tight routine is one of the main factors to ignore exercise and eat healthy food (Center for Health Promotion, Ministry of Health, 2009).

Not only in adulthood, many children and adolescents are also overweight and obese. In addition to increasing the risk of degenerative diseases, obesity in children can also increase the risk of low self- confidence, signs of depression, and the existence of stigmatization and discrimination. In 2010, more than 40 million children in the world who were less than five years old were overweight (WHO, 2012). In the United States, one of three children aged 2-19 years are overweight, and one of six are obese. In adolescents, $70 \%$ of overweight people will grow into overweight adults, and this will increase by $80 \%$ if one or both parents are overweight or obese. The prevalence of obesity in adolescents aged 12-19 years also increased to $18 \%$ from 2007 to 2008 when compared from 1973 to 1974 , where the prevalence of obesity was only $6 \%$. When compared with 1973 to 1974 , the proportion of children aged 5-17 years who were obese increased five times more from 2008 to 2009.

Based on the prevalence of research conducted in the United States, more than $50 \%$ of adults and more than $25 \%$ of children suffer from overweight and obesity. Very high presentations cause chronic disease epidemics. If obesity continues, then most of the population in the United States will suffer from obesity, where obese continues to increase from year to year [3].

The increasing prevalence of obesity needs serious attention because it could lead to various degenerative diseases. National Obesity Forum data mentioned that obesity contributes to 300,000 deaths/year [3]. Moreover, obesity can decrease self-confidence and cause serious psychological disorders. Besides, discrimination from the surrounding environment is frequently reported. If obesity occurs in adolescents, then these teens will grow into adolescents, contribute to a higher obese number [3].

Basic Health Research or Riskesdas data in 2007 showed that the prevalence of obesity in Indonesia in adolescents aged 15 years and over was 19.1\%, while for ages 6-14 years, the prevalence of obesity for the boy was $9.5 \%$ and the girl was $6.4 \%$. The results of Riskesdas in 2010 showed the prevalence of obesity in adolescents aged 13-15 years who were male by $2.9 \%$ and $2.0 \%$ for females, while for ages $16-18$ years respectively $1.3 \%$ and $1,5 \%$. (MOH RI, 2011).The prevalence of obesity in adolescents in Riau Province in 2007 included the fifth grade of $15.1 \%$, while in 2010 in Riau Province, the incidence of obesity included the eleventh rank of 10.95 .

Adolescence is a time when a person starts interacting with more environmental influences and experiences behavioral formation. Lifestyle changes in adolescents have a significant influence on eating habits. They are more active, eat more outside the home, and get a lot of influence in the choice of food. Overweight adolescents may pay attention to their physical changes, in addition to the long-term health risks they have, such as increased blood pressure and diabetes, social and emotional problems. As teenagers, overweight can lead to despair and cannot give full concentration while studying. Teenagers need to have a good understanding of no perfect body for everyone. The right weight for someone is not the same for others. In adolescents, especially teenagers in junior high school children, they pay less attention to eating patterns. The development and growth of children their age are very fast so that it is very important to control the eating pattern.

Prevention of adolescent obesity is entirely in the hands of parents and health workers because teenagers are generally unaware and less concerned about obesity problems. Several 
attempts can be made to reduce the occurrence of obesity: (1) Sports, (2) Reducing fat consumption, (3) Consuming more protein, (4) Consuming more fiber. [4].

Health promotion cannot be separated from tools. Education (media) is a tool used by educators in delivering educational / teaching materials. This tool is more often referred to as a teaching aid because it serves to help and demonstrate something in the education/teaching process. One of the types of teaching aids is hearing aids, which are tools that can help to stimulate the senses of the eye and the sense of the listener during the process of delivering education, such as television, videocassette. This tool is better known as Audio Visual Aids (AVA). In this teaching aid, knowledge can be perceived through the five senses. The more senses used, the more knowledge will be perceived [5].

The presence and development of this Audio Visual Aid (AVA) media will provide a realistic picture and increases memory retention because it is more interesting and easy to remember. The advantages of Audio-Visual Aids (AVA) media can foster interest in participating in counseling so that the goals of counseling can be achieved [6].

Based on the results of a survey conducted in three schools, namely SMP N 1 Pekanbaru, SMP N 3 Pekanbaru, and SMP N 5 Pekanbaru, it is known that SMP N 1 Pekanbaru is the school with the lowest knowledge of obesity. The research was conducted at SMPN 1 Pekanbaru because this junior high school is one of the junior high schools that has quite a large number of students and has an A accreditation.

The presence and development of Audio Visual Aid (AVA) media, especially Audio Visual Video, will provide a more realistic picture and increase memory retention, which of course, can better provide better understanding. So the problem statement in this study is how the Effectiveness of Health Education Using Audio-Visual Video Media on Changes in Youth Knowledge About Obesity in SMPN 1 Pekanbaru. The purpose of this study was to determine how is the Effectiveness of Health Education Using Audio-Visual Video Media on Changes in Adolescent Knowledge and Attitudes About Obesity in SMPN 1 Pekanbaru.

\section{Method}

The research is quantitative with a correlational research design using a quasiexperimental study approach. This research will be conducted at SMPN 1 Pekanbaru. The reason for choosing this location is because during the initial survey, the assessment of adolescent knowledge of obesity, SMPN 1 Pekanbaru scored the lowest compared to 3 other high schools that also the location of the Initial Survey. This research is planned to commence approximately one year (12 months) and will commence after the signing of the research contract. The population in this study was all students of SMPN 1 Pekanbaru of grades 1 and 2 , which is 435 students. The entire population will be sampled in this study.

Univariate analysis was performed on each variable from the results of the study. This analysis only results in the distribution and percentage of each variable. Bivariate AnalysisBivariate analysis is an analysis of the results of the independent variables that are thought to have a relationship with related variables. The data are analyzed by using SPSS program. The statistical test used in the calculation of the T-dependent test by determining the p-value, if p-value $<0.05$, then an alternative hypothesis (Ha) is accepted, which means that there is a change in the knowledge and attitudes of adolescents after counseling with AVA media. 


\section{Result}

Based on the results of research conducted on the Effectiveness of Health Education Using Audio-Visual Video Media on Changes in Youth Knowledge and Attitudes About Obesity in SMPN 1 Pekanbaru:

Table 1. Knowledge and Attitude Distribution of Students Before and After Counseling with AVA Media about Obesity at SMPN 1 Pekanbaru

\begin{tabular}{clcccc}
\hline No & \multicolumn{6}{c}{ Variable } & Mean & Median & SD & Minimum-Maximum \\
\hline 1 & $\begin{array}{l}\text { Prior Knowledge } \\
\text { (PreTest) }\end{array}$ & 24.67 & 24 & 3.831 & $16-31$ \\
\hline 2 & $\begin{array}{l}\text { Knowledge After } \\
\text { Counseling (Post } \\
\text { Test) }\end{array}$ & 26.29 & 27 & 3.700 & $15-31$ \\
& & & & \\
\hline
\end{tabular}

In table 1 , it can be seen that the average knowledge about Obesity before being given counseling with AVA media is 24.67, with a minimum value of 16 and a maximum value of 31. The average level of knowledge about Obesity after being given counseling with AVA media is 26.29 , with a minimum value of 15 and a maximum value of 31 . average attitude about Obesity before being given counseling with AVA media is 10.34 with a minimum value of 7 and a maximum value of 13 .

Table 2. Average Distribution of Respondent's Average Knowledge Before and After Counseling with

\begin{tabular}{cccccc}
\multicolumn{6}{c}{ AVA Media about Obesity in SMPN 1 Pekanbaru } \\
\hline Variable & Mean & SD & SE & P-Value & \multirow{2}{*}{ N } \\
\hline Pretest & 24.67 & 3.831 & 0.184 & \multirow{2}{*}{0.001} & \multirow{2}{*}{435} \\
\hline Post-test & 26.29 & 3.700 & 0.177 & \\
\hline
\end{tabular}

From Table 2, it can be seen the average in the pre-test knowledge is 24.67 , with a standard deviation of 3,831 . In the second measurement, the average post-test knowledge is 26.29 , with a standard deviation of 3,700 . The mean difference between the first and second measurements is 1,621 , with a standard deviation of 3,841 . The statistical test results obtained the value of 0.001 , so it can be concluded that there is a significant difference between the value of knowledge before being given counseling about Obesity with AVA media and after being given counseling about Obesity with AVA media.

\section{Discussion}

The average score on the pre-test of knowledge is 24.67 , with a standard deviation of 3,831 . In the second measurement, the average post-test knowledge is 26.29 , with a standard deviation of 3,700. The mean difference between the first and second measurements is 1,621, with a standard deviation of 3.84. Statistical test results obtained a value of 0.001 so that it can be concluded that there is a significant difference between the value of knowledge before 
being given counseling about Obesity with AVA media and after being given counseling about Obesity with AVA media.

Health Education is an application of the concept of education in the field of health. In terms of education, health education is a practical pedagogic or educational practice. Therefore the concept of health education is a concept that can be applied to the health sector. The basic concept of education is a learning process, which means that in education, there is a process of growth, development, or change towards an adult, better, and more mature in individuals, groups, and communities [7].

[8] health counseling is an educational activity carried out by spreading messages, instilling confidence so that people are not aware, know and understand but are also willing and ordinary a suggestion that has to do with health.

Health counseling is a combination of various activities and opportunities based on the principles of learning to achieve a situation, wherever individuals, families, groups, or communities as a whole want to live healthily, know how to and do what can be done, individually or in groups by asking help.

The use of audio-visual media in health promotion activities provides many advantages because it can present information, describes the process, explains complex concepts, teaches skills, shortens and slows time, and influence attitude. Thus, the use of audio-visual media in health education activities is expected to be able to change behavior gradually [8]. Audio Visual Video Media has several advantages, such as can draw attention to short periods of other external stimuli, difficult demonstrations can be prepared and recorded in advance so that the instructor's time can focus on the presentation [6].

The results of this study are in line with previous research conducted, based on the $t$ paired simple test in which there were differences in the knowledge of respondents before and after health education using posters, lecture methods, and questions and answers, with a significance level of $0.00(\mathrm{P}<0.005)$. The method is very effective in increasing students' knowledge about the prevention of obesity in SD Negeri 028 Bagansiapiapi. Research results prove that knowledge changes occur after being given health education using AVA media.

\section{Conclusion}

Before and after health education at SMP N 1 Pekanbaru, there was effectiveness regarding the use of audiovisual video media on the level of changes in adolescent knowledge about obesity, and there were significant differences in knowledge between before and after health education was given with a significance value of $0.001(\mathrm{p}<0.005)$.

\section{Suggestion}

The school can adopt the methods and media used in this study to educate students about the importance of preventing obesity in high school students. 


\section{References}

[1] Darmayanti. 2008. How to Overcome Overweight in Adolescents. Yogyakarta: Curvaksara

[2] Sadiman, A.S., Rahardjo, R., Haryono, A., Rhadjito. 2012. Education Media of understanding, development and pemanfaatannya. Jakarta: PT. Raja Grafindo Persada

[3] Soegih. 2009. Obesity: The Problem and The Theraphy. EGC. Jakarta

[4] Simatupang, M.R. 2008. The Effect of Consumption Pattern and Physical Activity. North Sumatra University, North Sumatra.

[5] Notoatmodjo. 2010.Metodologi Penelitian Kesehatan. Jakarta : Rineka Cipta

[6] Sadiman, A.S., Rahardjo, R., Haryono, A., Rhadjito. 2012. Media pendidikan pengertian, pengembangan, dan pemanfaatannya. Jakarta: PT. Raja Grafindo Persada

[7] Notoatmodjo. 2011 .Kesehatan Masyarakat Ilmu Dan Seni .Jakarta : Rineka Cipta

[8] Notoatmodjo, S. 2007.Health Promotion and Behavioral Sciences.Jakarta : Rineka Cipta 